\title{
Pengaruh kapasitas sumber daya manusia, pemanfaatan teknologi, dan komitmen organisasi terhadap kualitas laporan keuangan di pemerintahan Kota Medan
}

\author{
Ayu Kristina Br Hombing*; Reggy Reynatasya Pandiangan; Dona \\ Simangunsong; Yois Nelsari Malau
}

Prodi Akuntansi, Fakultas Ekonomi, Universitas Prima Indonesia, Medan

*E-mail korespodensi: ayusihombing292@gmail.com

\begin{abstract}
The purpose of this study was to determine and analyze the effect of human resource capacity, technology utilization, and organizational commitment on the quality of financial reports in the city government of Medan. The research method used is a quantitative approach. The method of analysis used in this study is Multiple Linear Regression. The results of the determination coefficient analysis obtained a value of 0.118 , which means that the Variable Variable of Quality of Financial Statements which can be explained by Variable Variations in Human Resource Capacity, Utilization of Technology and Organizational Commitment is 8\% while the remaining $92 \%$ is explained by other independent variables such as Internal Control, Understanding Accounting Standards The research results show that Simultaneously Human Resources, Technology Utilization, and Organizational Commitment do not have a positive and insignificant effect on the Quality of Partial Financial Statements. Human Resources and Organizational Commitment have no negative and insignificant effect on the Quality of Financial Statements. Technology Utilization Variable Partially has a positive and significant effect on the Quality of Financial Statements.
\end{abstract}

Keywords: Human resources, Technology utilization, Organizational commitment, Quality of cash report.

\begin{abstract}
Abstrak
Tujuan Penelitian ini adalah untuk mengetahui dan mengnalisis Pengaruh Kapasitas Sumber Daya Manusia, Pemanfaatan Teknologi, dan Komitmen Organisasi terhadap Kualitas Laporan Keuangan di Pemerintahan Kota Medan. Metode Penelitian yang digunakan yairu Pendekatan Kuantitatif. Metode Analisis yang digunakan dalam Penelitian adalah Regresi Linier Berganda. Hasil Analisis Koefisien Determinasi diperoleh nilai 0,118 artinya Variasi Variabel Kualitas Laporan Keuangan yang dapat dijelaskan oleh Variasi Variabel Kapasitas Sumber Daya Manusia, Pemanfaatan Teknologi dan Komitmen Organisasi adalah sebesar 8\% sedangkan sisanya $92 \%$ dijelaskan oleh variabel bebas lainnya seperti : Pengendalian Intern, Pemahaman Standart Akuntansi. Hasil Penelitian menunjukan bahwa Secara Simultan Sumber Daya Manusia, Pemanfaatan Teknologi, dan Komitmen Organisasi tidak berpengaruh positif dan tidak sigifikan terhadap Kualitas Laporan Keuangan Secara Parsial. Sumber Daya Manusia dan Komitmen Organisasi tidak berpengaruh negatif dan tidak signifikan terhadap Kualitas Laporan Keuangan. Secara Parsial Variabel Pemanfaatan Teknologi berpengaruh positif dan signifikan terhadap Kualitas Laporan Keuangan.
\end{abstract}

Kata kunci : Sumber daya manusia, Pemanfaatan teknologi, Komitmen organisasi, Kualitas laporan keuangan. 


\section{PENDAHULUAN}

Sejauh ini kita melihat semakin tingginya tuntutan masyarakat atas kinerja pemerintahan, baik pemerintahan kota maupun pemerintahan daerah. Pemerintah dituntut agar dapat menciptakan laporan keuangan yang berkualitas yang baik salah satunya Dinas Pemerintah Kota Medan. Pemerintahan Kota Medan merupakan pusat dari seluruh dinas di Medan yang memiliki 34 cabang di Medan. Dinas Pemerintah Kota ini pusat dari semua dinas yang melaporkan kinerja keuangan, mengelolah keuangan, dan yang mengalokasikan dana. Pemerintah Kota Medan harus mampu melaporkan laporan keuangan yang memberikan informasi keuangan yang berkualitas.

Dalam menyajikan laporan keuangan yang berkualitas diperlukannya dukungan sumber daya manusia,pemanfaatan teknologi,dan komitmen dalam suatu organisasi.Sumber Daya Manusia merupakan salah satu aset penting yang harus dimiliki suatu perusahaan.Suatu perusahaan memerlukan sumber daya manusia yang berkompeten,berpengalaman,dan memiliki tanggung jawab atas perkerjaannya untuk dapat mencapai tujuan perusahaan,dengan adanya sumber daya manusia yang berkualitas diharapkan sumber daya manusia dapat memanfaatkan kemajuan teknologi saat ini.Perkembangan teknologi yang begitu pesat sangat berpengaruh terhadap penyajian dan pembuatan laporan keuangan dari data dan informasi yang diperoleh,dengan memanfaatkan teknologi dan penggunaan jaringan internet diharapkan dapat mempercepat pembuatan laporan keuangan yang berkualitas. Suatu organisasi juga memerlukan komitmen yang tinggi untuk dapat mencapai tujuannya, karena komitmen organisasi ini mencerminkan tingkat dimana seseorang mengenali sebuah organisasi dan terikat pada tujuan- tujuannya. Tingginya komitmen yang dimiliki seseorang menentukan kualitas dan kemajuan dalam organisasinya.

Berdasarkan artikel yang didapat dari tribun-medan.com , Pemerintahan Kota Medan (Pemko) mendapat penilaian opini Wajar Dengan Pengecualian (WDP) dari Badan Pemeriksa Keuangan (BPK) Republik Indonesia Perwakilan Sumut atas hasil pemeriksaan Laporan Keuangan Pemerintah Daerah (LKPD) Tahun Anggaran 2017, Senin (6/8/2018). Belum lengkapnya pendataan aset yang dilakukan menjadi salah satu penyebab Pemko Medan belum mendapatkan opini Wajar Tanpa Pengecualian (WTP). Hal ini terungkap ketika Wakil Kota Medan Drs.H.T.Dzulmi Eldin,S.Msi, diwakili Sekda Kota Medan Ir.H.Syaiful Bahri Lubis, MM, menerima hasil pemeriksaan LKPD Tahun Anggaran 2017 dari Kepala BPK Perwakilan Sumut Vicentia Ambar Wahyuni di Auditorium BPK Perwakilan Sumut Jalan Imam Bonjol Medan, Senin (6/8/2018). Sekda Kota Medan mengatakan belum berhasilnya Pemko Medan mendapatkan opini WTP karena masih ada yang harus dilakukan perbaikan terkait masalah aset. Dikatakan Sekda, aset yang dimiliki Pemko Medan sampai saat ini belum terdaftar dengan baik dan lengkap. Masih ada dokumentasi pencatatan aset itu kurang lengkap, padahal itu harus lengkap. Itu tidak terlepas dari masa lalu, bukan kesalahan orang yang sekarang. Jadi kita akan terus melakukan perbaikan dan mencari dokumen untuk melengkapinya," kata Sekda.Selanjutnya mantan Kepala Bappeda Kota Medan itu menambahkan, apa yang menjadi kekurangan dari hasil pemeriksaan yang telah dilakukan auditor BPK Perwakilan Sumut akan terus ditindaklanjuti. "Dengan kemauan dan kerja keras dari seluruh jajaran Pemko Medan serta bimbingan penuh dari BPK Perwakilan Sumut, kekurangan itu akan kita penuhi. Insha Allah tahun depan kita mendapat penilaian opini WTP," kata Sekda. Sementara itu Wakil Ketua DPRD Medan H.Iswanda Nanda Ramli, mengucapkan terima kasih kepada BPK Perwakilan Sumut yang telah melakukan pemeriksaan terhadap LKPD Pemko Medan. Dengan pemeriksaan yang 
dilakukan itu, diharapkannya pengelolaan keuangan Pemko Medan akan menjadi lebih baik lagi setiap tahunnya."DPRD Medan melihat LKPD Pemko Medan sudah baik namun harus terus ditingkatkan lagi. Apalagi tahun ini, penilaian yang diberikan kepada Pemko Medan dengan predikat WDP. Dengan penilaian ini kita harapkan pengelolaan keuangan Pemko Medan terus ditingkatkan lagi sehingga menjadi lebih transparan dan akuntabel lagi ke depannya," harap Nanda Ramli.

Berdasarkan permasalah diatas, dapat dilihat bahwa kualitas laporan keuangan di Indonesia belum memenuhi karakteristik kualitatif yang telah diisyaratkan,. Sehingga pemerintah perlu membenahi dan memperhatikan laporan keuangan, agar menghasilkan laporan keuangan yang berkualitas sesuai dengan karakteristik kualitas yang telah diisyaratkan.

Peneliti mengambil penelitian tentang kualitas laporan keuangan seperti Sumber Daya Manusia terhadap kualitas laporan keuangan guna untuk melihat sejauh mana suatu perusahaan mencapai tujuannya. Dengan demikian perusahaan dapat menggunakan rasio ini untuk pedoman dalam suatu perusahaannya. Pengembangan sumber daya manusia merupakan suatu upaya yang dilakukan untuk mengembangkan kualitas atau kemampuan sumber daya manusia agar mampu mengelola dan mengolah kualitas laporan keuangan yang ingin dicapai suatu organisasi. Bagaimanapun canggihnya sarana dan prasarana ataupun teknologi yang dimiliki suatu perusahaan, bila tidak ditunjang oleh Sumber Daya Manusia (SDM) yang memiliki kemampuan yang memadai, maka niscaya organisasi tersebut sulit untuk berkembang. Dengan demikian, Sumber Daya Manusia merupakan peran penting dalam suatu organisasi.

Selanjutnya pemanfaatan teknologi terhadap kualitas laporan keuangan, kemajuan teknologi informasi yang saat ini berkembang pesat serta pemanfaatannya yang secara luas, maka dapat memberikan peluang bagi pihak untuk mengelolah, mengakses, dan memperdayagunakan informasi keuangan daerah secara cepat dan akurat. Kewajiban pemanfaatan teknologi oleh Pemerintah dan Pemerintah Daerah diatur dalam Peraturan Pemerintah Nomor.56 Tahun 2005 tentang Sistem Informasi Keuangan Daerah. Sistem teknologi dapat membantu proses pencatatan dan pelaporan keuangan. Dengan dimanfaatkannnya teknologi saat ini, diharapkan dapat mempermudah pihak perusahaan untuk mendapatkan informasi. Dengan pemanfaatan teknologi, informasi keuangan menjadi berkualitas, yaitu akurat, tepat waktu, dan relevan.

Selanjutnya adalah komitmen organisasi terhadap kualitas laporan keuangan, organisasi merupakan suatu unit yang terkoordinasi yang terdiri dari dua orang atau lebih, yang berfungsi untuk mencapai satu sasaran (tujuan) tertentu atau serangkaian sasaran (Rivai, dkk 2012:171). Komitmen organisasi merupakan sebagai tingkat kekuatan identifikasi individu, dan keterkaitan individu kepada organisasi yang memiliki kepercayaan yang kuat dan menerima nilai-nilai dan tujuan perusahaan. Kedua, kemauang yang kuat untuk bekerja keras dalm suatu organisasi. Ketiga, keinginan untuk tetap menjadi anggota organisasi. Dengan demikian dengan adanya komitmen yang kuat dalam suatu organisasi maka pekerjaan dalam suatu organisasi akan terlaksana dengan baik, sebaliknya tanpa adanya komitmen dalam suatu organisasi maka pekerjaan-pekerjaan akan sulit terlaksana.

\section{LANDASAN TEORI}

\section{Teori pengaruh kapasitas sumber daya manusia terhadap kualitas laporan keuangan}

Menurut Sutrisno (2016:3) mengatakan bahwa, Sumber Daya Manusia (SDM) merupakan satu-satunya sumber daya yang memiliki akal perasaan, keinginan, keterampilan, pengetahuan, dorongan, daya, dan karya. Semua potensi SDM tersebut 
berpengaruh terhadap upaya organisasi dalam mencapai tujuannya. Jika bagaimanapun majunya teknologi, perkembangan informasi, tersedianya modal, jika tanpa Sumber Daya Manusia (SDM) sulit bagi organisasi untuk mencapai tujuannya. Kualitas sumber daya manusia ditentukan oleh 3 faktor utama, yaitu : pendidikan, kesehatan, dan ekonomi yang memadai ( Notoatmodjo, 2009: 3). Artinya Sumber Daya Manusia yang berkompeten akan mampu membuat laporan keuangan yang berkualitas.

Menuru t Hasibuan (2016:224) Sumber Daya Manusia adalah kemapuan terpadu dari karya pikir dan daya fisik yang dimiliki oleh individu. Jika kapasitas sumber daya manusia berpengaruh positif terhadap kualitas laporan keuangan, maka kualitas laporan keuangan akan memenuhi karakteristik kualitatif, yakni : relevan, andal, dapat dibandingkan, dan dapat dipahami (Tanjung 2012:13-15).

\section{Teori pengaruh pemanfaatan teknologi terhadap kualitas laporan keuangan}

Menurut Lucas (2000), (dalam Kadir,2014:10) Teknologi Informasi adalah segala bentuk teknologi yang diterapkan untuk memproses dan mengirimkan dalam bentuk elektronis.

Menurut Alter (1992), (dalam Kadir, 2014:10) Teknologi mencakup perangkat keras dan perangkat lunak untuk melaksanakan satu atau sejumlah tugas pemroresan data seperti menangkap, mentransmisikan, menyimpan, mengambil, memanipulasi, atau menampilkan data. Teknologi informasi tidak hanya terbatas pada teknologi komputer yang digunakan untuk memproses dan menyimpan informasi melainkan juga mencakup teknologi komunikasi untuk mengirimkan informasi (dalam Martin,1999).

\section{Teori pengaruh komitmen organisasi terhadap kualitas laporan keuangan}

Triatna (2015:125) Komitmen organisasi adalah suatu keadaan di mana seorang karyawan memihak pada suatu organisasi tertentu beserta tujuannya dalam berniat memelihara keanggotaan dalam organisasi itu.

Menurut Kreitner (2014:165) Komitmen organisasi (organizational commitment) mencermintakan tingkat dimana seseorang mengenali sebuah organisasi dan terikat pada tujuan-tujuannya. Ini adalah sikap kerja yang penting karena orang-orang yang memiliki komitmen diharapkan bisa menunjukkan kesediaan untuk bekerja lebih keras demi mencapai tujuan organisasi dan memiliki hasrat yang lebih besar untuk tetap bekerja di suatu perusahaan.

\section{METODE}

\section{Populasi dan sampel}

Populasi adalah wilayah generasi yang terdiri : objek/subjek yang mempunyai kualitas dan karakteristik tertentu yang ditetapkan oleh penelitian untuk dipelajari dan kemudian ditarik kesimpulannya (Sugiono, 2016:80).Teknik penarikan sample dilakukan dengan metode purposive sample atau dengan menentukan kriteria tertentu terhadap sample. Kriteria yang telah ditetapkan oleh peneliti yaitu berdasarkan usia,jenis kelamin,tingkat pendidikan,latar belakang pendidikan,dan lama berkerja di SKPD. Populasi dalam penelitian ini adalah seluruh perangkat dinas kota medan yang berjumlah 34 SKPD dengan total responden berjumlah `138 responden.

Kisioner

\section{Dentifikasi dan defenisi operasional variabel penelitian}

Menurut Sugiono (2016:39) variabel penelitian yang digunakan dalam penelitian ini adalah : 


\section{Variabel independen}

Variabel ini sering disebut sebagai variabel stimulus,preditor,antecedent. Dalam bahasa indonesia sering disebut dengan variabel bebas. Varibel bebas adalah variabel yang mempengaruhi atau yang menjadi sebab perubahannya atau timbulnya variabel dependen((terikat). Dalam penelitian ini variabel independennya meliputi Kapasitas Sumber Daya Manusia (X1), Pemanfaatan teknologi (X2), Komitmen Organisasi (X3).

\section{Variabel dependen}

Variabel ini sering disebut variabel output, kriteria, konsumen. Dalam Bahasa Indonesia sering disebut sebagai variabel terikat. Variabel terikat merupakan variabel yang dipengaruhi atau yang menjadi akibat karena adanya variabel bebas. Dalam penelitian ini variabel dependennya meliputi Kualitas Laporan Keuangan (Y).

Identifikasi dan Defenisi Operasional Variabel penelitian ini dapat dilihat pada tabel.

Tabel 1. Operasional variabel

\begin{tabular}{|c|c|c|c|}
\hline Variabel & Definisi Variabel & $\begin{array}{l}\text { Indikator } \\
\text { Variabel }\end{array}$ & $\begin{array}{l}\text { Skala } \\
\text { Pengu } \\
\text { kuran }\end{array}$ \\
\hline $\begin{array}{l}\text { Kapasitas } \\
\text { Sumber } \\
\text { Daya } \\
\text { Manusia }\end{array}$ & $\begin{array}{l}\text { Sumber Daya Manusia } \\
\text { merupakan perwujudan dari } \\
\text { kemampuan terpadu } \\
\text { daya pikir dan daya fisik yang } \\
\text { dimiliki } \\
\text { individu, perilaku dan sifatnya } \\
\text { ditentukan oleh keturunan dan } \\
\text { lingkungannya,sedang } \\
\text { prestasi kerjanya dimotivasi oleh } \\
\text { keinginan untuk memenuhi } \\
\text { kepuasannya } \\
\text { 2013:1) (Darmawan }\end{array}$ & $\begin{array}{l}\text { 1. Tanggung } \\
\text { Jawab } \\
\text { 2. Pelatihan } \\
\text { 3. Pengalaman }\end{array}$ & Skala likert \\
\hline $\begin{array}{l}\text { Pemanfaatan } \\
\text { Teknologi }\end{array}$ & $\begin{array}{l}\text { Teknologi Informasi adalah } \\
\text { seperangkat alat yang membantu } \\
\text { anda bekerja dengan informasi dan } \\
\text { melakukan tugas-tugas yang } \\
\text { berhubungan dengan pemprosesan } \\
\text { informasi (Haag,dkk 1996), } \\
\text { (dalam Triwahyuni,dkk2013) }\end{array}$ & $\begin{array}{l}\text { 1. Komputer } \\
\text { 2. Jaringan } \\
\text { 3. Internet }\end{array}$ & $\begin{array}{l}\text { Skala } \\
\text { Likert }\end{array}$ \\
\hline $\begin{array}{l}\text { Komitmen } \\
\text { Organisasi }\end{array}$ & $\begin{array}{l}\text { Allen dan Meyer 1990 (dalam, } \\
\text { Darmawan 2013: } 168 \text { ) } \\
\text { mendefenisikan } \\
\text { organisasi sebagai sebuah konsep } \\
\text { yang memiliki tiga dimensi yaitu } \\
\text { effective, normative, dan } \\
\text { continuace comitmment. }\end{array}$ & $\begin{array}{l}\text { 1. Kepercayaan } \\
\text { 2. Kesiapan } \\
\text { Untuk Bekerja } \\
\text { Keras } \\
\text { 3. Keinginan } \\
\text { yangkuat }\end{array}$ & $\begin{array}{l}\text { Skala } \\
\text { Likert }\end{array}$ \\
\hline
\end{tabular}

\section{Keterangan:}

Fenomena sosial, yaitu skala yang berisi dua tingkat preferensi jawaban dengan pilihan dimana: 1 = Sangat Tidak Setuju (STS), 2= Tidak Setuju (TS), 3= Ragu-Ragu (RR), 4= Setuju (S), 5= Sangat Setuju (SS) 


\section{HASIL DAN PEMBAHASAN}

\section{Deskriptif data}

Penelitian ini dilakukan di 34 SKPD PEMKO MEDAN, dari 138 kuesioner yang disebarkan ke 34 SKPD PEMKO MEDAN diperoleh 65 lembar atau 47,2\% yang kembali, kesioner yang dapar digunakan sebanyak 48 lembar atau 35\%, 17 lembar atau 12,4\% kuesioner tidak dapat digunakan karena tidak memiliki data yang lengkap , 73 lembar atau 52,8\% kuesioner tidak dapat digunakan karena melampaui batas waktu yang ditentukan oleh Peneliti. Dari 48 lembar koesioner yang diolah, terdapat responden berjenis kelamin perempuan sebanyak 21 orang atau $44 \%$ dan laki-lak sebanyak 27 orang atau 56\%. Jumlah responden terbanyak terdapat pada usia 36-50 tahun sebanyak 34 orang atau $71 \%$, dengan masa kerja terbanyak yaitu 2-5 tahun sebanyak 26 orang atau 54,2\%. Dilihat dari tingkat pendidikan sebagian besar responden pendidikan S1 sebanyak 26 orang atau 54\%, D3 sebanyak 10 orang atau $21 \%$, S2 sebanyak 6 orang atau 12,5\% dan tingkat pendidikan lainnya sebanyak 6 orang atau $12,5 \%$, dengan latar belakang pendidikan paling banyak yaitu latar belakang pendidikan lainnya seperti: Pendidikan, Fisika, Banking,Hukum,Sosial,SLTA sebanyak 18 orang atau 37,5\%, Akuntansi sebanyak 15 orang atau 31\%, Manajemen sebanyak 13 orang atau $27,5 \%$,dan yang terakhir Pertanian sebanyak 2 orang atau $4 \%$.

\section{Uji validitas dan reliabilitas istrumen variabel}

\section{Uji validitas instrumen variabel}

Menurut Ghozali (2016:52), uji validitas digunakan untuk mengukur atau valid tidaknya suatu kuesioner. Suatu kuesioner valid jika pertanyaan pada kuesioner mampu mengungkapkan sesuatu yang akan diukur oleh kuesioner tersebut.

Uji signifikan dilakukan dengan membandingkan nilai $r_{\text {hitung }}$ dengan $r_{\text {tabel }}$ untuk degree of freedom $(\mathrm{df})=0,05, \mathrm{n}-2=48-2=46$, didapat $\mathrm{r}_{\text {tabel }}=0,2845$. Uji validitas untuk masing-masing pertnyaan pada Kapasitas Sumber Daya Manusia, Pemanfaatan Teknologi, Komitmen Organisasi dan Kualitas Laporan Keuangan di Pemerintahan Kota Medan yang memiliki hasil $r_{\text {hitung }}>r_{\text {tabel }}$ yakni $r_{\text {hiung }}>0,2845$ maka setiap pertanyaan dinyatakan valid.

Tabel 2. Uji reabilitas intrumen varibel

\begin{tabular}{llll}
\hline \multicolumn{1}{c}{ Kuesioner } & \multicolumn{1}{c}{$\begin{array}{c}\text { Alpha } \\
\text { Cronbach }\end{array}$} & Nilai Kritis & \multicolumn{1}{c}{ Keterangan } \\
\hline Sumber Daya Manusia & 0,754 & 0,6 & Reliabel \\
Teknologi Informasi & 0,724 & 0,6 & Reliabel \\
Komitmen Organisasi & 0,778 & 0,6 & Reliabel
\end{tabular}

Sumber : Data diolah, 2020

Dari Hasil Uji Reliabilitas diatas menunujukan bahwa Sumber Daya Manusia , Pemanfaatn Teknologi, dan Komitmen Organisasi memiliki nilai Cronbach's Alpha lebih besar dari 0.6, maka dapat diartikan Reliabel atau dapat diandalkan.

Berdasarkan Tabel 3 menunjukkan bahwa sumber daya manusia, pemanfaatan 
teknologi, komitmen organisasi dan kualitas laporan keuangan memilki 48 sampel,dengan hasil sebagai berikut : 1).Sumber Daya Manusia memiliki nilai minimum 14 yang terdapat pada Dinas Perpustakaan dan Kearsipan,nilai maximum 39 pada Badan Pengelola Keuangan dan Aset Daerah, Inspektorat, dan Dinas Pendidikan,mean 32,48 dan standard deviasi 4,115. 2).

Tabel 3. Statistik deskriptif

Descriptive Statistics

\begin{tabular}{lrrrrr}
\hline & N & Minimum & Maximum & Mean & $\begin{array}{c}\text { Std. } \\
\text { Deviation }\end{array}$ \\
\hline Sumber Daya Manusia & 48 & 14 & 39 & 32,48 & 4,115 \\
Teknologi Informasi & 48 & 24 & 35 & 29,10 & 2,676 \\
Komitmen Organisasi & 48 & 18 & 29 & 23,75 & 3,035 \\
Kualitas Laporan & 48 & 28 & 45 & 37,65 & 3,917 \\
Keuangan & 48 & & & & \\
Valid N (listwise) & & & & & \\
\hline
\end{tabular}

Sumber : Data diolah, 2020

Pemanfaatan Teknologi memiliki nilai minimum 24 yang terdapat pada Dinas Pendidikan, Dinas Ketenagakerjaan, Dinas Sosial,Dinas Perindustrian.Nilai maximum 35 pada Dinas Komunikasi dan Informatika, Badan Penelitian dan Pengembangan, mean 29,10 dan standard deviasi 2,676. 3).Komitmen Organisasi memiliki nilai minimun 18 yang terdapat pada Dinas Perumahan,Kawasan Permukiman,dan Penataan Ruang, Dinas Perpustakaan dan Kearsipan,Dinas Kabudayaan.Nilai maximum 29 pada Satuan Polisi Pamong Praja,Inspektorat, mean 23,75,dan standard deviasi 3,035. 4).Kualitas Laporan Keuangan memiliki nilai minimum 28 yang terdapat pada Dinas Perdagangan.Nilai maximum 45 pada Badan Pengelola Keuangan dan Aset Daerah, mean 37,65, dan standard deviasi 3,917.

\section{Hasil uji asumsi klasik}

\section{Uji normalitas}

Berdasarkan Gambar 1 di atas, telihat gambar garis berbentuk lonceng, tidak melonceng ke kiri maupun ke kanan, maka dinyatakan normal

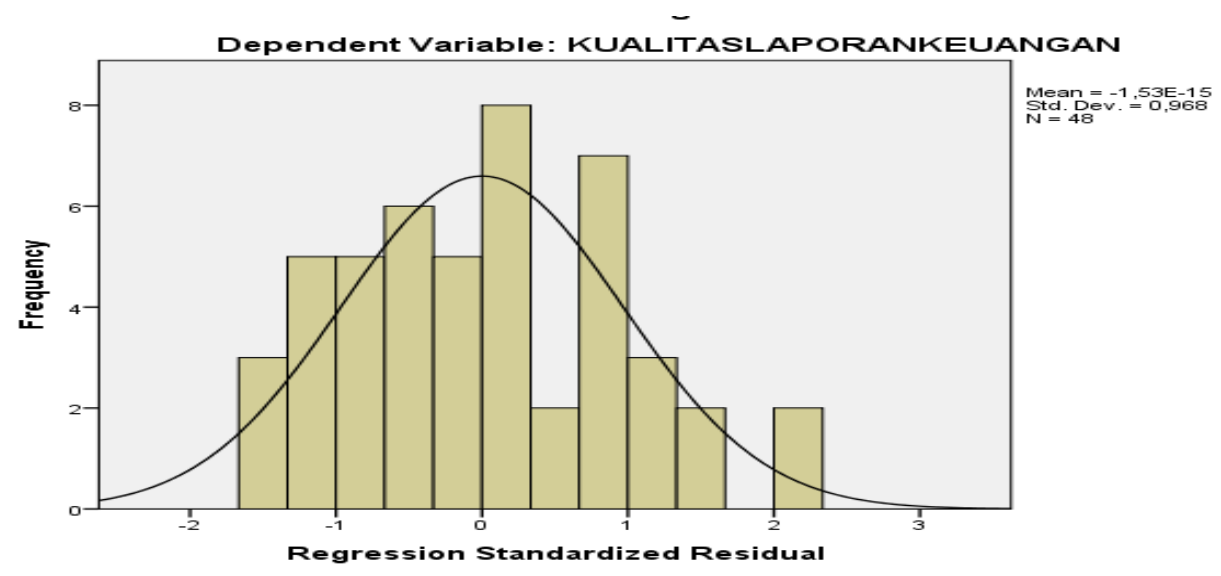

Sumber : Data diolah, 2020

Gambar 1. Grafik histogram 


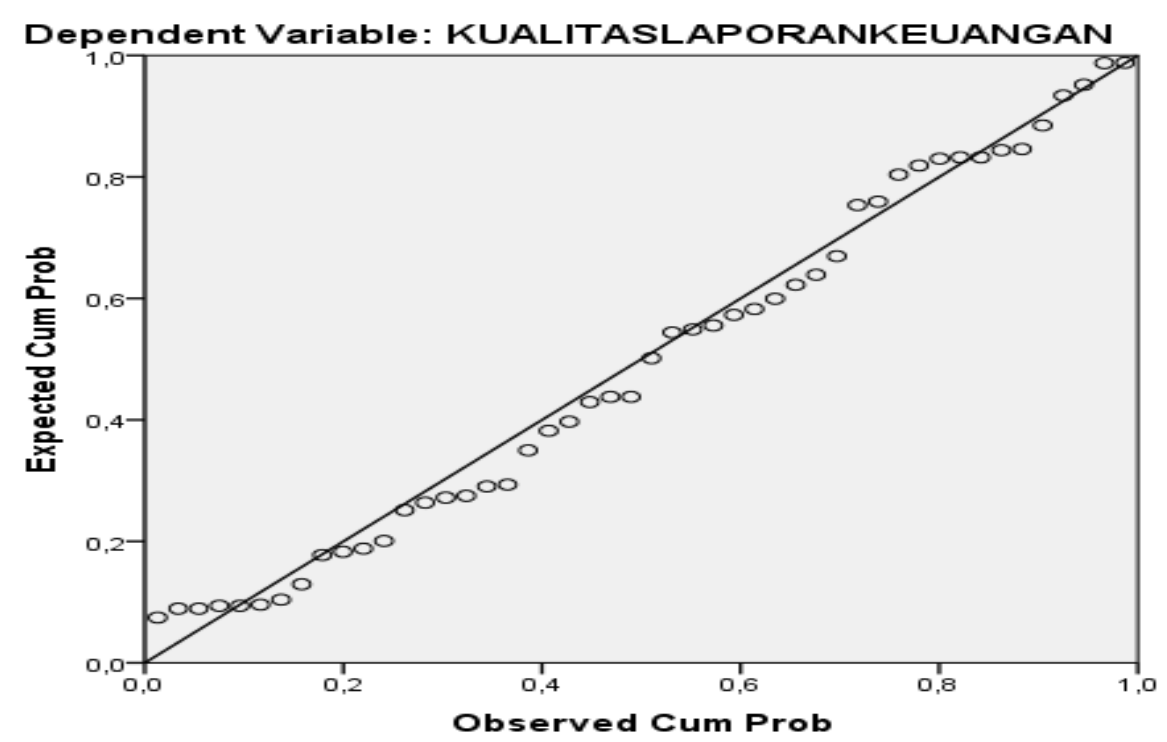

Sumber : Data diolah, 2020

Gambar 2. p plot

Transformasi pada Gambar 2 menunjukkan data (titik-titik) menyebar di sekitar garis diagonal dan mengikuti garis diagonal. Jadi dari gambar tersebut dapat diambilkesimpulan bahwa residual pada model regresi tersebut berdistibusi secara normal.

Tabel 4. One-sample kolmogorov-smirnov test

\begin{tabular}{llc}
\hline & & $\begin{array}{c}\text { Unstandardized } \\
\text { Residual }\end{array}$ \\
\hline $\mathbf{N}$ & & $\mathbf{4 8}$ \\
Normal Parameters & a,b & Mean \\
& Std. Deviation & 2,29000000 \\
Most Extreme & Absolute &, 088 \\
Differences & Positive &, 088 \\
& Negative &,- 068 \\
Test Statistic & &, 088 \\
Asymp. Sig. (2-tailed) & &, $200^{\mathrm{c,d}}$ \\
\hline
\end{tabular}

Sumber : Data diolah, 2020

Dari Tabel 4 menunjukkan bahwa seluruh data variabel yang digunakan terdistribusi secara normal. Karena memiliki nilai signifikan diatas 0,05 adalah yaitu 0,20. Pada Tabel 5 menunjukkan hasil uji multikolonieritas sebagai berikut : 1).Sumber Daya Manusia dengan nilai tolerence $0,701>0,10$ dan nilai VIF sebesar 1,426 < 10. 2). 2).Pemanfaatan Teknologi dengan nilai tolerence $0,781>0,10$ dan nilai VIF sebesar $1,280<10.3)$.Komitmen Organisasi dengan nilai tolerence $0,782>0,10$ dan nilai VIF sebesar 1,278 <10.4). Dan Hasil IV.4 diatas menunjukan bahwa Sumber Daya Manusia, 
Pemanfaatan Teknologi, dan Komitmen Organisasi memiliki nilai tolenrence $>10$, VIF $<10$,maka tidak terjadi gejala multikolonieritas.

Tabel 5. Uji multikolonieritas

Coefficients $^{\mathbf{a}}$

\begin{tabular}{|c|c|c|c|}
\hline & \multirow{2}{*}{ Model } & \multicolumn{2}{|c|}{ Collinearity Statistic } \\
\hline & & Tolerence & VIF \\
\hline \multirow[t]{4}{*}{1} & (Constant) & & \\
\hline & SDM & ,701 & 1,426 \\
\hline & PemanfaatanTeknologi & ,781 & 1,280 \\
\hline & KomitmenOrganisasi & ,782 & 1,278 \\
\hline
\end{tabular}

\section{Uji heteroskedastisitas}

Dari grafik scatterplot pada gambar 4 terlihat titik-titik menyebar secara acak (random) baik diatas maupun di bawah angka 0 pada sumbu Y. Hal ini dapat disimpulkan bahwa tidak terjadi heteroskedastisitas pada model regresi.

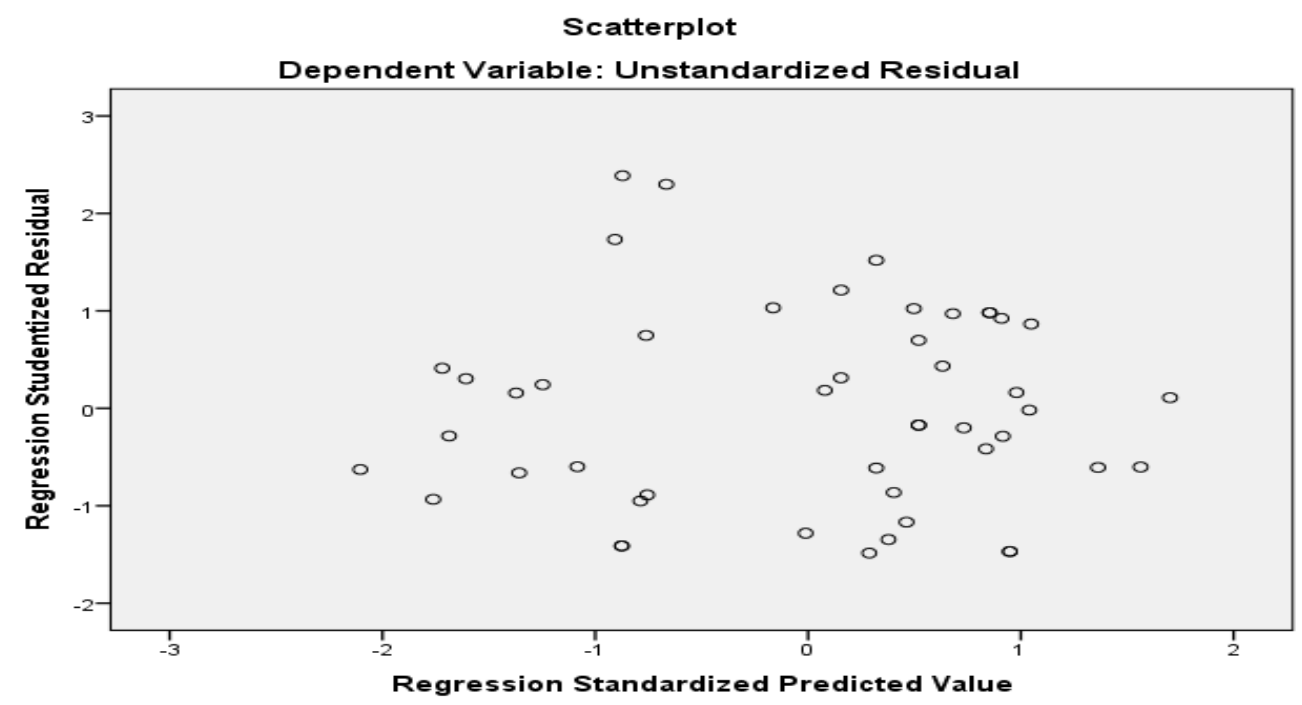

Sumber : Data diolah, 2020

Gambar 4. Grafik scatterplot

Tabel 6. Hasil uji heteroskedastisitas (uji park)

\begin{tabular}{llcr}
\hline & Model & $\mathbf{t}$ & \multicolumn{2}{c}{ Sig } \\
\hline 1 (Constant) &, 303 &, 763 \\
& LN_SDM & 1,668 &, 102 \\
& LN_Pemanfaatan Teknologi &, 543 &, 590 \\
& LN_Komitmen Organisasi & $-2,666$ &, 011 \\
\hline
\end{tabular}

Sumber : Data diolah, 2020

Melalui data Tabel 7, maka persamaan regresi linier berganda yang terdapat dalam penelitan ini adalah Sebagai berikut : 
Tabel 7. Hasil pengujian regresi linier berganda

\begin{tabular}{|c|c|c|c|}
\hline & \multirow{2}{*}{ Model } & \multicolumn{2}{|c|}{ Unstandardized Coefficients } \\
\hline & & $\mathbf{B}$ & Std.Error \\
\hline & (Constant) & 1,745 & 4,151 \\
\hline & SDM & ,420 & ,101 \\
\hline & Pemanfaatan Teknologi &, 545 &, 147 \\
\hline & Komitmen Organisasi & ,269 &, 129 \\
\hline
\end{tabular}

\section{Kua_LK $=1,745+0,420$ SDM + 0,545 Pemanfaatan Teknologi + 0,269 Komitmen Organisasi}

Penjelasan untuk persamaan regresi linier berganda tersebut adalah: 1).Nilai konstanta sebesar 1,745 artinya jika variabel independen dianggap nol, maka nilai Kualitas Laporan Keuangan 1,745 satuan. 2).Nilai koefisien Kapasitas Sumber Daya Manusia sebesar 0,420 artinya nilai Kapasitas Sumber Daya Manusia mengalami kenaikan atau memiliki arah positif, hal ini berarti setiap kenaikan satu satuan Kapasitas Sumber Daya Manusia maka akan diikuti kenaikan Kualitas Laporan Keuangan sebesar 0,420 satuan. 3).Nilai Koefisien Pemanfaatan Teknologi sebesar 0,545 artinya Nilai Pemanfaatan TeknologinMengalami kenaikkan atau memiliki arah positif, hal ini berarti setiap kenaikkan satu kesatuan Pemanfataan Teknologi Maka akan diikuti Kenaikkan Kualitas Laporan Keuangan sebesar 0,545. 4).Nilai koefisien Komitmen Organisasi sebesar 0,269 artinya nilai Komitmen Organisasi mengalami kenaikan atau memiliki arah positif, hal ini berarti setiap kenaikan satu kesatuan Komitmen Organisasi maka akan diikuti kenaikan Kualitas Laporan Keuangan sebesar 0,269 satuan.

Tabel 8. Koefisien determinasi $\left(\mathrm{R}^{2}\right)$

\begin{tabular}{llcr} 
& \multicolumn{3}{c}{ Model Summary $^{\mathbf{b}}$} \\
\hline Model & R & R Square & Adjusted R Square \\
&, $810^{\mathrm{a}}$ &, 656 &, 632 \\
\hline 1 & & & \\
\hline
\end{tabular}

Sumber : Data diolah, 2020

Nilai Adjusted $R$ Square adalah 0,632 atau 63,2\% artinya kemapuan variabel bebas Sumber Daya Manusia,Komitmen Organisasi,dan Pemanfaatan Teknologi dalam menjelaskan variabel terikat yaitu Kualitas Laporan Keuangan adalah sebesar 63,2\% sedangkan 36,8\% dijelaskan oleh variabel lain yang tidak diteliti dalam penelitian ini misalnya pengendalian internal,pemahaman sistem akuntansi.

Berdasarkan Tabel 9 pada penelitian ini diketahui jumlah sampel (n) adalah 48 dan jumlah keseluruhan variabel(k) adalah 4,sehingga diperoleh: 1).df (pembilang) $=\mathrm{k}-$ $1=4-1=3$, dan 2).df (penyebut) $=n-k=48-3=45$. Berdasarkan hasil uji simultan (uji F) pada tabel IV.10 diatas, diperoleh nilai Fhitung adalah sebesar 27,935, signifikan 0,000. Hasil Ftabel adalah 2,81. 
Tabel 9. Pengujian hipotesis secara simultan (Uji F)

\begin{tabular}{llllllll}
\multicolumn{7}{c}{ ANOVA $^{\mathbf{a}}$} \\
\hline 1 & & $\begin{array}{l}\text { Sum of } \\
\text { Squares }\end{array}$ & $\begin{array}{l}\text { D } \\
\text { f }\end{array}$ & $\begin{array}{l}\text { Mean } \\
\text { Square }\end{array}$ & F & Sig. \\
\hline & Regression & 472,763 & 3 & & 157,588 & 27,935 &, 000 \\
& & & & & \\
Residual & 248,261 & 44 & 5,641 & & \\
& Total & 720,979 & 47 & & & \\
\hline
\end{tabular}

Sumber : Data diolah, 2020

Dengan demikian, nilai Fhitung $<$ Ftabel $(27,935>2,81)$ dan signifikan 0,05>0,000, menyatakan Sumber Daya Manusia,Pemanfaatan Teknologi, dan Komitmen Organisasi secara simultan berpengaruh positif dan signifikan terhadap Kualitas Laporan Keuangan di Pemerintahan Kota Medan.

Tabel 10. Pengujian hipotesis secara parsial (Uji t)

\begin{tabular}{|c|c|c|c|c|c|c|}
\hline \multicolumn{7}{|c|}{ Coefficients $^{\mathrm{a}}$} \\
\hline & \multirow[t]{2}{*}{ Model } & \multicolumn{2}{|c|}{$\begin{array}{l}\text { Unstandardized } \\
\text { Coefficients }\end{array}$} & \multirow{2}{*}{$\begin{array}{c}\begin{array}{c}\text { Standardized } \\
\text { Coefficients }\end{array} \\
\text { Beta } \\
\end{array}$} & \multirow[t]{2}{*}{$\mathbf{t}$} & \multirow{2}{*}{$\begin{array}{l}\mathrm{S} \\
\mathbf{g}\end{array}$} \\
\hline & & B & Std.Error & & & \\
\hline \multirow[t]{4}{*}{1} & (Constant) & 1,745 & 4,151 & & ,420 & ,676 \\
\hline & SDM & ,420 & ,101 & ,441 & 4,177 & ,000 \\
\hline & Pemanfaatan &, 545 & , 147 &, 373 & 3,723 & ,001 \\
\hline & $\begin{array}{l}\text { Komitmen } \\
\text { Organisasi }\end{array}$ & ,269 &, 129 & ,209 & 2,085 & ,043 \\
\hline
\end{tabular}

Sumber : Data diolah, 2020

Berdasarkan Tabel 10 menunjukkan bahwa nilai tabel untuk signifikan 0,05 pada 2 arah dan pada derajat kebebasan n-k-1 = 48-4-1 = 45 adalah sebesar 2,01410 Dengan demikian dapat dijelaskan sebagai berikut : 1).Sumber Daya Manusia memiliki nilai $t_{\text {hitung }}$ sebesar 4,177 dan sig 0,000, maka $t_{\text {hitung }}>t_{\text {tabel }}(4,177>2,01410)$ Sig 0,05 > 0,000 artinya Sumber Daya Manusia berpengaruh positif dan signifikan terhadap Kualitas Laporan Keuangan di Pemerintahan Kota Medan. 2).Pemanfaatan Teknologi memiliki nilai $t_{\text {hitung }}$ sebesar 3,732 dan sig 0,001, maka $t_{\text {hitung }}>t_{\text {tabel }}(3,732>2,01410)$ Sig $0,05>0,001)$ artinya Pemanfaatan Teknologi berpengaruh positif dan signifikan terhadap Kualitas Laporan Keuangan di Pemerintahan Kota Medan. Komitmen

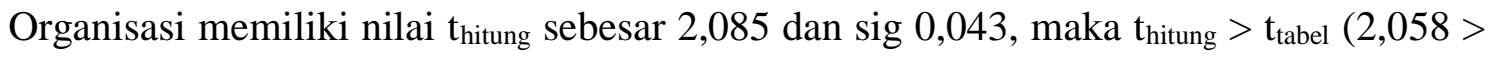
2,01410) Sig 0,05> 0,043, artinya Komitmen Organisasi berpengaruh postif dan signifikan terhadap Kualitas Laporan Keuangan di Pemerintahan Kota Medan.

\section{Pengaruh kapasitas sumber daya manusia terhadap kualitas laporan keuangan}

Penelitian ini menunjukkan bahwa secara parsial kapasitas sumber daya manusia berpengaruh positif dan signifikan terhadap kualitas laporan keuangan. Penelitian ini sesuai dengan teori Larasati (2018:43) menyatakan bahwa Sumber Daya Manusia merupakan aset utama organisasi yang menjadi perencana dan palaku 
aktif setiap aktivitas organisasi.Kualitas dan kuantitas sumber daya manusia dalam suatu organisasi harus disesuaikan dengan kebutuhan organisasi yang bersangkutan supaya efektif dan efisien dalam menunjang tercapainya tujuan.Berdasarkan teori tersebut dapat memperkuat bahwa sumber daya manusia sangat mempengaruhi kualitas laporan keuangan.

Hasil penelitian ini konsisten dengan hasil penelitian Trisna (2015)yang berjudul "Pengaruh Kapasitas Sumber Daya Manusia, Pengendalian Internal Akuntasi, Dan Pemanfaatan Teknologi Informasi Terhadap Kualitas Laporan Keuangan" hasilnya menunjukkan bahwa Sumber Daya Manusia berpengaruh dan signifikan terhadap Kualitas Laporan Keuangan.

\section{Pengaruh pemanfaatan teknologi informasi terhadap kualitas laporan keuangan}

Penelitian ini menunjukkan bahwa secara parsial Pemanfaatan Teknologi Informasi berpengaruh positif dan signifikan terhadap kualitas laporan keuangan. Penelitian ini sesuai dengan teori Irwansyah,dkk (2014:83) yang menyatakan bahwa teknologi informasi merupakan sistem yang mampu mengurangi waktu yang diperlukan untuk menghitung,mencatat,mengelompokkan serta meringkas informasi akuntansi yang tepat waktu dan akurat untuk keperluan pengambilan keputusan yang sangat penting bagi para pengguna laporan keuangan.Artinya,semakin tinggi pemahaman seseorang terhadap teknologi informasi maka semakin baik dan akurat kualitas laporan keuangan yang dihasilkan.

Hasil Penelitian ini Konsisten dengan hasil Penelitian Firdaus (2015) yang berjudul "Pengaruh Kualitas Sumber Daya Manusia, Pemanfaatan Teknologi Informasi, dan Penerapan Kebijakan Akuntansi Terhadap Kualitas Laporan Keuangan Pemerintah Kota Banda aceh" Hasilnya Menunjukkan Bahwa Pemanfaatan Teknologi Informasi berpengaruh dan signifikan terhadap Kualitas Laporan Keuangan.

\section{Pengaruh komitmen organisasi terhadap kualitas laporan keuangan}

Penelitian ini menunjukkan bahwa secara parsial Komitmen Organisasi berpengaruh positif dan signifikan terhadap Kualitas Laporan Keuangan. Penelitian ini sesuai dengan teori Bukit,dkk (2017:34) yang menyatakan bahwa Pekerja dengan komitmen organisasi yang tinggi akan tetap membantu pada saat organisasi mengalami kesulitan,sedangkan pekerja dengan komitmennya rendah akan meninggalkan organisasinya untuk mendapatkan pekerjaan yang lebih baik.Artinya komitmen organisasi yang dimiliki seseorang mempengaruhi hasil dari kualitas laporan keuangan.

Penelitian ini menunjukkan bahwa secara parsial Komitmen Organisasi berpengaruh positif dan signifikan terhadap Kualitas Laporan Keuangan. Hasil penelitian ini konsisten dengan hasil penelitian Liza (2017) yang berjudul "Pengaruh Sistem Pengendalian Intern, Teknologi Informasi, Kualitas Sumber Daya Manusia, dan Komitmen Organisasi Terhadap Kualitas Laporan Keuangan " hasilnya menunjukkan bahwa Komitmen Organisasi berpengaruh dan signifikan terhadap Kualitas Laporan Keuangan.

\section{KESIMPULAN DAN SARAN}

\section{Kesimpulan}

Secara parsial variabel Kapasitas Sumber Daya Manusia berpengaruh dan signifikan terhadap Kualitas Laporan Keuangan di Pemerintahan Kota Medan. Secara 
parsial variabel Pemanfaatan Teknologi berpengaruh dan signifikan terhadap Kualitas Laporan Keuangan di Pemerintahan Kota Medan. Secara parsial variabel Komitmen Organisasi berpengaruh dan signifikan terhadap Kualitas Laporan Keuangan di Pemerintahan Kota Medan. Pengaruh Kapasitas Sumber Daya Manusia, Pemanfaatan Teknologi, dan Komitmen Organisasi secara simultan berpengaruh terhadap Kualitas Laporan Keuangan di Pemerintahan Kota.

\section{Saran}

Berdasarkan hasil penelitian yang dilakukan, maka saran yang dapat di berikan oleh peneliti dalam penelitian ini adalah : 1). Diharapkan agar pemerintahan kota Medan dapat melihat pengaruh kapasitas sumber daya manusia, pemanfaatan teknologi, dan komitmen organisasi terhadap laporan keuangan yang relevan, andal, dapat dibandingkan, dan dapat dipahami. 2). Diharapkan peneliti selanjutnya dapat menambahkan variable yang berbeda dari variable penelitian ini seperti: pengendalian intern, pemanfaatan system informasi akuntansi,dll, sehingga akan diperoleh hasil penelitian yang dapat dijadikan sebagai pembanding terhadap penelitian terdahulu. Selain itu penelitian juga dapat dilakukan pada pemerintahan didaerah lain. 3).Diharapkan hasil penelitian ini dapat dijadikan referensi dalam penyajian ilmu pengetahuan bagi perpustakaan dengan pengaruh kapasitas sumber daya manusia, pemanfaatan teknologi, dan komitmen organisasi terhadap kualitas laporan keuangan.

\section{DAFTAR PUSTAKA}

Abdul Hafiz Tanjung.(2012).Akuntansi Pemerintahan Daerah Berbasis Aktual Alfabeta: Bandung

Abdul Kadir. (2014). Pengenalan Sistem Informasi. Andi Offset: Yogyakarta

Benjamin Bukit,dkk. (2017). Pengembangan Sumber Daya Manusia. Zahir Publishing. Yogyakarta .

Larasati, Sri. (2016). Manajemen Sumber Daya Manusia: Deepublish: Yogyakarta.

Edy Irwansyah, dkk. (2014). Pengantar Teknologi Informasi. Deepublish: Yogyakarta.

Edy Sutrisno. (2016). Manajemen Sumber Daya Manusia. Prenadamedia Group: Jakarta

Firdaus., Nadirsyah., Heru, F.(2015) Pengaruh Kualitas Sumber Daya Manusia Pemanfaatan Teknologi Informasi dan Penerapan Kebijakan Akuntansi Terhadap Kualitas Laporan Keuangan Pemerintah Kota Banda Aceh. Jurnal Magister Akuntansi Pascasarjana Universitas Syariah Kuala, 4(1), 45-54.

Ghozali,I. (2011). Aplikasi Analisis Multivariate dengan Program IBM SPSS 19: Unidip Press: Semarang.

Liza, M., Yossi, D., Zuraida. (2017) Pengaruh Sistem Pengendalian Intern, Teknologi Informasi, Kualitas Sumber Daya Manusia dan Komitmen Organisasi Terhadao Kualitas Laporan Keuangan. Jurnal Perspektif Ekonomi Darusalam, 3(2), 151-164.

Melayu S.P. Hasibuan. (2016). Manajemen Sumber Daya Manusia Cet.19. Bumi Perkasa: Jakarta

Ni Made, T.S., Gst Ayu, P., Edy , S. (2015) Pengaruh Kapasitas Sumber Daya Manusia, Pengendalian Internal Akuntansi, dan Pemanfaatan Teknologi Informasi Terhadap Kualitas Laporan Keuangan. e-journal S1 Ak Universitas Pendidikan Genesha, 3(1), 1-12 
Noprial, V.M. (2015) Pengaruh Kualitas Sumber Daya Manusia , Komitmen Organisasi, Sistem Pengendalian Intern, dan Pemanfaatan Teknologi Informasi Terhadap Kualitas Laporan Keuangan (Studi Empiris Pada SKPD Kabupaten Indragiri Hulu). JOM. FEKON. 2(2), 1-15

Rober Kreitner, Angelo Kinicki. (2014). Perilaku Organisasi Ed.9 - Cet.1. McGraw: Jakarta Selatan.

Soekidjo Notoatdjo. (2009). Pengembangan Sumber Daya Manusia Cet.4. Rineka Cipta :Jakarta.

Sugiono. (2016). Metode Penilitian Kuantitaf, Kualitatif, dan R\&D. Alfabeta: Bandung

Veithzal Rivai, Deddy Mulyadi. (2012). Kepemimpinan dan Perilaku Organisasi Ed.2. Rajawali Pers: Jakarta. 